\title{
PENGARUH POLA ASUH ORANGTUA TERHADAP KEDISIPLINAN PESERTA DIDIK DI SMK TEKNINDO JAYA DEPOK
}

\author{
Mohammad Ramadona ${ }^{1}$, Anita Riskia Anjani ${ }^{2(*)}$, Ria Putriani ${ }^{3}$ \\ Universitas Indraprasta PGRI, Indonesia ${ }^{12}$ \\ Universitas Muhammadiyah Jakarta, Indonesia ${ }^{3}$ \\ mohammadramadona1@gmail.com ${ }^{1}$, riskianita888@gmail.com ${ }^{2}$, putrianiriacantik@gmail.com ${ }^{3}$
}

\begin{tabular}{lll}
\hline & & \\
Received: & 26 Agustus 2019 \\
Revised: & 04 November 2019 \\
Accepted: & 10 November 2019
\end{tabular}

\begin{abstract}
Keluarga merupakan sarana pendidikan yang sangat penting bagi pembentukan karakter anak. Untuk itu, pola asuh dan pola pendidikan sangat menentukan dalam menciptakan karakteristik anak yang baik bagi masyarakat di masa depan, dan hal ini dimulai dari kedisiplinan anak dalam menata hidupnya. Berangkat dari pentingnya hal tersebut, penelitian ini bertujuan untuk mengukur apakah ada pengaruh antara pola asuh orang tua terhadap kedisiplinan peserta didik di SMK Teknindo Jaya Depok. Metode penelitian yang digunakan bersifat deskriptif kuantitatif dengan menggunakan teknik simple random sampling. Pengumpulan data dilakukan melalui wawancara dan studi literatur dengan variabel yang diteliti adalah variabel $\mathrm{X}$ (Pola Asuuh Orang Tua) dan variabel Y (Kedisiplinan). Hasil penelitian yang dilakukan membuktikan hipotesis $\mathrm{Ha}$ bahwa ada pengaruh yang positif antara pola asuh orang tua terhadap kedisiplinan peserta didik kelas $\mathrm{X}$ di SMK Teknindo Jaya dengan konstanta regresi (a) sebesar 12,4 dan koefisien regresi (b) sebesar 1,14 dengan rumus $\mathrm{Y}=12,4+1,14 \mathrm{X}$. Koefisien korelasi menunjukkan hasil sebesar $87 \%$ dan koefisien determinasi sebesar $75 \%$ dengan hasil hipotesis uji t-hitung > t-tabel yaitu sebesar 17,016 > 1,9858. Artinya, ada hubungan dan keterikatan serta saling memengaruhi antara pola asuh orang tua terhadap kedisiplinan siswa.
\end{abstract}

Keywords: Keluarga, Pola Asuh, Kedisiplinan, Pendidikan

(*) Corresponding Author: $\quad$ Anita Riskia Anjani, riskianita888@gmail.com, 087770943347

How to Cite: Ramadona, M., Anjani, A. R., \& Putriani, R. (2020). Pengaruh Pola Asuh Orangtua Terhadap Kedisiplinan Peserta Didik Di SMK Teknindo Jaya Depok. Research and Development Journal of Education, 6(2), 13-23.

\section{INTRODUCTION}

Keluarga merupakan wadah pendidikan yang sangat besar pengaruhnya dalam perkembangan anak. Oleh karena itu pendidikan anak tidak dapat dipisahkan dari keluarganya karena keluarga merupakan tempat pertama kali anak belajar menyatakan diri sebagai makhluk dalam berinteraksi dengan kelompoknya. Keluarga mempunyai peranan dan tanggungjawab utama atas perawatan dan perlindungan anak sejak bayi hingga remaja. Selain keluarga, secara khusus orangtua juga mempunyai peranan sangat berpengaruh dalam perkembangan seorang anak. Terutama akan kemana seorang anak akan menentukan masa depannya. Mengasuh, membesarkan dan mendidik merupakan tugas mulia orangtua.

Keluarga merupakan lingkungan pendidikan pertama dan utama. Dikatakan pertama karena disinilah seseorang pertama kali mendapatkan pendidikan dan dikatakan utama karena disini pula seseorang memperoleh dasar atau bekal untuk melangkah pada 
kehidupan selanjutnya. Pendidikan agama, moral, dan nilai sebagai dasar untuk berkehidupana pertama kali ditanamkan dalam lingkungan keluarga. Pola asuh orangtua dalam lingkungan keluarga akan mendorong pribadi peserta didik dalam tata pergaulannya di sekolah dan di masyarakat.

Dalam jurnal (Arifin \& Ummah, 2018), pola asuh merupakan sikap orangtua dalam mengadakan hubungan atau berinteraksi dengan diamati dari cara orangtua memberikan peraturan, hadiah, disiplin, hukuman, pemberian perhatian dan tanggapan terhadap keinginan atau kehendaknya, dengan kata lain, pola asuh orangtua adalah kesatuan dari sikap orangtua dalam memelihara, mendidik dan membimbing anak secara optimal.

Salah satu konsep dari pola asuh orangtua adalah untuk mengembangkan kedisiplinan terutama dalam kedisiplinan belajar, sehingga sebagai orangtua mampu menerapkan pengasuhan yang sesuai dan dapat menumbuhkan sikap-sikap yang positif yang diharapkan dapat menjadi bekal untuk masa depannya.

Kedisiplinan peserta didik ditunjukkan dengan ketaatan terhadap aturan-aturan belajar. Peraturan belajar yang harus ditaati tidak hanya peraturan sekolah, namun juga peraturan di rumah. Peserta didik dapat disebut disiplin apabila mampu mematuhi aturanaturan di sekolah dengan baik, serta mengikuti pembelajaran di kelas secara tertib. Kedisiplinan peserta didik juga dapat dilihat dari kepatuhan terhadap peraturan belajar di rumah yang ditunjukkan dengan belajar sesuai jadwal yang ditentukan mengerjakan pekerjaan rumah tepat waktu.

Berdasarkan observasi yang dilakukan peneliti di SMK Teknindo Jaya Depok, ditemukan ketidakdisiplinan seperti terlambat datang ke sekolah, tidak masuk sekolah tanpa keterangan. Ketidakdisiplinan yang berlangsung secara terus menerus akan berdampak pada kebiasaan berperilaku tidak disiplin.

Orangtua sering pasrah menyerahkan peserta didik tentang pendidikan kepada sekolah atau instansi pendidikan lainnya, sehingga menimbulkan pemikiran bahwa orangtua memiliki sedikit peran dalam mendidik peserta didik. Pemikiran tersebut harus dibenahi, karena pada dasarnya pendidikan ataupun sikap perilaku tidak sepenuhnya menjadi tanggung jawab sekolah melainkan peran orangtua yang pertama karena sebagian besar harinya anak berada di lingkungan kelurga terutama bersama orangtua. Keluarga mempunyai peran besar terhadap pendidikan formal maupun non formal yang diajarkan kepada anak-anaknya sehingga orangtua merupakan dasar yang menjadi landasan pertama dalam pembentukan pribadi anak. Pengasuhan yang dilakukan orangtua sangat berperan besar terutama dalam menumbuhkan sikap kedisiplinan.

Berdasarkan latar belakang masalah tersebut, pertanyaan yang harus dijawab oleh peneliti dalam merumuskan masalah tersebut adalah, adakah pengaruh pola asuh orangtua terhadap kedisiplinan peserta didik di SMK Teknindo Jaya Depok?.

\section{KAJIAN PUSTAKA}

\section{Kedisiplinan}

\section{a. Pengertian Kedisiplinan}

Kedisiplinan berasal dari kata sifat yaitu disiplin, yang diberi imbuhan ke-an. Menurut (Garmo, 2013, p. 45) kedisiplinan adalah kualitas inti dari tanggung jawab pribadi. Kedisiplinan diri terlihat melalui kerapihan, ketepatan waktu, sikap hemat, dan lain-lain. Kata disiplin berasal dari bahasa Latin "disciplina" yang artinya pemberian instruksi untuk suatu disiplin". Kedisiplinan adalah suatu perhatian dan tujuan hidup dari kualitas karakter.Kedisiplinan memampukan seseorang untuk berkonsentrasi dalama mencapai tujuan, baik di bidang pendidikan, olahraga, musik, 
bisnis, atau hubungan antarpribadi. Menurut (Garmo, 2013, p. 45) kedisiplinan adalah suatu perhatian dan tujuan hidup dari kualitas karakter.Kedisiplinan memampukan seseorang untuk berkonsentrasi dalam mencapai tujuan, baik dibidang pendidikan, olahraga, musik, bisnis, atau hubungan antarpribadi. McKee dkk. dalam (Lestari, 2012, p. 63) kedisiplinan merupakan salah satu bentuk dari upaya orangtua untuk melakukan control terhadap anak.

\section{b. Pentingnya Kedisiplinan}

Menurut Maman Rahman dalam (Tu'u, 2008, pp. 35-36)) pentingnya kedisiplinan bagi peserta didik sebagai berikut: 1) Memberi dukungan bagi terciptanya perilaku yang tidak menyimpang. 2) Membantu peserta didik memahami dan menyesuaikan diri dengan tuntutan lingkungan. 3) Cara menyelesaikan tuntutan yang ingin di tunjukkan peserta didik terhadap lingkungannya. 4) Untuk mengatur keseimbangan keinginan individu satu dengan individu lainnya. 5) Menjauhi peserta didik melakukan hal-hal yang dilarang sekolah. 6) Mendorong peserta didik melakukan hal-hal yang baik dan benar. 7) Peserta didik belajar hidup dengan kebiasaan- kebiasaan yang baik, positif dan bermanfaat baginya dan lingkungannya. 8) Kebiasaan baik itu menyebabkan ketenangan jiwanya dan lingkungannya.

\section{c. Fungsi Kedisiplinan}

Fungsi kedisiplinan menurut Tu'u (2008) adalah sebagai berikut:

1) Menata Kehidupan Bersama

Kedisiplinan berguna untuk menyadarkan peserta didik bahwa dirinya perlu menghargai orang lain dengan cara menaati dan mematuhi peraturan yang berlaku. Ketaatan dan kepatuhan itu membatasi dirinya merugikan pihak lain, tetapi hubungan dengan sesama menjadi baik dan lancar.

2) Membangun Kepribadian

Pertumbuhan kepribadian seseorang biasanya dipengaruhi oleh faktor lingkungan keluarga, lingkungan pergaulan, lingkungan masyarakat, lingkungan sekolah. Disiplin yang diterapkan di masing-masing lingkungan tersebut memberi dampak bagi pertumbuhan kepribadian yang baik. Oleh karena itu, dengan disiplin, seseorang dibiasakan mengikuti, mematuhi, menaati aturan-aturan yang berlaku. Kebiasaan itu, lama-kelamaan masuk ke dalam kesadaran dirinya sehingga akhirnya menjadi milik kepribadiannya. Disiplin telah menjadi bagian dalam kehidupannya sehari-hari.

3) Melatih Kepribadian

Sikap, perilaku dan pola kehidupan yang baik dan berdisiplin tidak terbentuk sertamerta dalam waktu singkat. Namun, terbentuk melalui satu proses yang membutuhkan waktu panjang. Salah satu proses untuk membentuk kepribadian tersebut dilakukan melalui latihan. Demikian juga dengan kepribadian yang tertib, teratur, taat, patuh, perlu dibiasakan dan dilatih.

4) Pemaksaan

Kedisiplinan dapat pula terjadi karena adanya pemaksaan dan tekanan dari luar. Misalnya, ketika seorang peserta didik yang kurang disiplin masuk ke satu sekolah yang berdisiplin baik, terpaksa harus menaati dan mematuhi tata tertib yang ada di sekolah tersebut.

5) Hukuman

Tata tertib biasanya berisi hal-hal positif yang harus dilakukan oleh peserta didik. Sisi lainnya berisi sanki atau hukuman bagi yang melanggar tata tertib tersebut.

6) Menciptakan Lingkungan Kondusif 
Kedisiplinan berfungsi mendukung terlaksananya proses dan kegiatan pendidikan agar berjalan lancar. Peraturan yang dirancang dan di implementasikan dengan baik, memberi pengaruh bagi terciptanya lingkungan pendidikan yang kondusif bagi kegiatan pembelajaran.

\section{d. Pembentukan Kedisiplinan}

Menurut Tu'u (Tu'u, 2008, p. 48) keempat faktor ini merupakan faktor dominan yang mempengaruhi dan membentuk kedisiplinan, sebagai berikut.

1) Kesadaran diri sebagai pemahaman diri bahwa disiplin dianggap penting bagi kebaikan dan keberhasilan dirinya.

2) Pengikutan dan ketaatan sebagai langkah penerapan dan praktik atas peraturanperaturan yang mengatur perilaku individunya.

3) Alat pendidikan untuk mempengaruhi, mengubah, membina dan membentuk perilaku yang sesuai dengan nilai-nilai yang ditentukan atau diajarkan.

4) Hukuman sebagai upaya menyadarkan, mengoreksi dan meluruskan yang salah sehingga orang kembali pada perilaku yang sesuai dengan harapan.

Menurut Tu'u (Tu'u, 2008, p. 49) selain keempat faktor tersebut, masih ada beberapa faktor lain lagi yang dapat berpengaruh pada pembentukan disiplin individu, antara lain teladan, lingkungan berdisiplin, dan latihan berdisiplin.

1) Teladan

Pembuatan dan tinndakan kerap kali lebih besar pengaruhnya dibandingkan dengan kata-kata. Karena itu contoh keteladanan dan disiplin atasan, kepala sekolah dan guru-guru serta penata usaha sangat berpengaruh terhadap kedisiplinana peserta didik.

2) Lingkungan Berdisiplin

Seseorang dapat juga dipengaruhi oleh lingkungan. Bila berada di lingkungan berdisiplin, seseorang dapat terbawa oleh lingkungan tersebut.

3) Latihan Berdisiplin

Kedisiplinan dapat dicapai dan dibentuk melalui proses latihan dan kebiasaan. Dengan latihan dan membiasakan diri, disiplin akan terbentuk dalam diri peserta didik.

Jadi, pembentukan kedisiplinan ternyata harus melalui proses panjang, dimulai sejak dini dalam keluarga dan dilanjutkan sekolah. Hal-hal penting dalam pembentukan ini terdiri dari kesadaran diri, kepatuhan, tekanan, sanki, teladan, lingkungan disiplin, dan latihan-latihan.

\section{e. Konsep Upaya Orangtua Dalam Membantu Peserta Didik Memiliki dan Mengembangkan Dasar-dasar Kedisiplinan}

Menurut Moh. Shochib (Shochib, 2014, pp. 14-16), konsep upaya orang tua dalam membantu peserta didik adalah sebagai berikut:

1) Pertemuan Makna antara Orangtua Dengan Peserta Didik

Untuk mengamati secara cermat, mendalam, dan menyeluruh upaya orangtua dalam membantu peserta didik memiliki dan mengembangkan dasar-dasar kedisiplinan, perlu diarahkan pada empat hal,yaitu : (1) pribadi orangtua yang konkret, (2) pribadi anak yang konkret, (3) situasi lugas dalam kehidupan keluarga (4) arah tindakan untuk anak agar memiliki dasar-dasar kedisiplinan dan mengembangkannya sebagaimana yang dijelaskan oleh M.I.Solaeman dalam Shochib (Shochib, 2014, p. 14). Keempat fenomena ini dapat dijadikan instrument untuk mengungkapkan: 
a) Pola Pertemuan, yaitu dapat tidaknya cara dan kualitas pertemuan antara orangtua sebagai pendidik dan anak sebagai si terdidik yang interaksinya bersifat nonsubjek.

b) Kualitas penghayatan dan komunikasi anak terhadap orangtuanya baik sebagai ibu atau ayah maupuun sebagai pendidik.

2) Pola Asuh Orangtua dalam membantu Peserta Didik Memiliki dan Mengembangkan Dasar-dasar Kedisiplinan

a) Pola Asuh Orangtua

Pola Asuh Orangtua dalam membantu peserta didik untuk mengembangkan kedisiplinan ini adalah upaya orangtua yang diaktualisasikan terhadap penataan (1) lingkungan fisik, (2) lingkungan sosial dan eksternal, (3) pendidikan eksternal dan internal, (4) dialog dengan peserta didiknya, (5) suasana psikologis, (6) sosio budaya, (7) perilaku yang ditampilkan pada saat terjadinya"pertemuan" dengan peserta didik, (8) kontrol terhadap perilaku peserta didik, dan (9) menentukan nilai-nilai moral sebagai dasar berperilaku dan yang diupayakan kepada pesert didik.

b) Anak Berdisiplin Diri

Anak berdisiplin diri dimaksudkan sebagai keteraturan perilaku berdasarkan nilai moral yang telah mempribadi dalam dirinya tanpa tekanan atau dorongan dari faktor eksternal.

c) Keterkaitan Pola Asuh Orangtua dengan Kedisiplinan

Keterkaitan pola asuh orangtua dengan kedisiplinan peserta didik dimaksudkan sebagai upaya orangtua dalam "meletakkkan" dasar-dasar disiplin kepada peserta didik dan membantu mengembangkannya sehingga peserta didik memiliki kedisiplinan.

d) Dinamika Peserta Didik Memiliki Kedisiplinan

Dinamika peserta didik memiliki dan mengembangkan dasar-dasar kedisiplinan melibatkan tiga prosesyang masing-masing bersifat dialektik, yaitu pengenalan dan pemahaman niali-nilai moral, pengendapan nilai-nilai moral, dan pempribadian niali-nilai moral.

\section{Peserta Didik}

Menurut Desmita (Desmita, 2016, p. 39) dalam proses pendidikan, peserta didik merupakan salah satu komponen manusiawi yang menempati posisi sentral. Peserta didik menjadi pokok persoalan dan tumpuan perhatian dalam semua proses transformasi yang di sebut pendidikan. Sebagai salah satu komponen penting dalam sistem pendidikan, peserta didik serimg disebut sebagai "raw material" (bahan mentah). Dalam perspektif pedagogis, peserta didik diartikan sebagai sejenis makhluk "homo educandum" makhluk yang menghajatkan pendidikan. Dalam pengertian ini, peserta didik dipandang sebagai manusia yang yang memiliki potensi yang bersifat laten, sehingga dibutuhkan binaan dan bimbingan untuk mengaktualisasikannya agar ia dapat menjadi manusia susila yang cakap.

Dalam perspektif psikologis, peserta didik adalah individu yang sedang berada dalam proses pertumbuhan dan perkembangan, baik fisik maupun psikis menurut fitrahnya masing-masing. Sebagai individu yang tengah tumbuh dan berkembang, peserta didik memerlukan bimbingan dan pengarahan yang konsisten menuju ke arah titik optimal kemampuan fitrahnya. Arifin dalam (Desmita, 2016, p. 39). Menurut Sudarwan Danim (Danim, 2010, p. 1), Peserta Didik merupakan sumberdaya utama dan terpenting dalam proses pendidikan formal. 
Berdasarkan beberapa definisi tentang peseerta didik yang disebutkan di atas dapat disimpulkan bahwa peserta didik individu yang memiliki sejumlah karakteristik, dalam (Desmita, 2016, p. 40) di antaranya:

1) Peserta didik adalah individu yang memiliki potensi fisik dan psikis yang khas, sehingga ia merupakan insan yang unik. Potenti-potensi khas yang dimilikinya ini perlu dikembangkan dan diaktualisasikan.

2) Peserta didik adalah individu yang sedang berkembang. Artinya, peserta didik tengah mengalami perubahan-perubahan dalam dirinya secara wajar, baik yang ditujukan kepada diri sendiri maupun yang diarahkan pada penyesuaian dengan limgkungannya.

3) Peserta didik adalah individu yang membutuhkan bimbingan individual dan perlakuan manusiawai. Sebagai individu yang sedang berkembang, maka proses pemberian bantuan dan bimbingan perlu mengacu pada tingkat perkembangannya.

4) Peserta didik adalah individu yang memiliki kemampuan untuk mandiri. Dalam perkembangannya peserta didik memilki kemampuan untuk berkembang kearah kedewasaan. Disamping itu, dalam diri peserta didik juga terdapat kecenderungan untuk melepaskan diri dari keberuntungan pada pihak lain. Karena itu, setahap demi setahap orangtua atau pendidik perlu memberikan kesempatan kepada peserta didik untuk mandiri dan bertanggung jawab sesuai dengan kepribadiannya sendiri.

\section{Kedisiplinan Peserta Didik}

Menurut Nanang Martono (Martono, 2014, p. 110) kedisiplinan peserta didik ditujukan agar mereka dapat memelihara kebiasaanya ketika bergabung dalam lingkungan masyarakat secara nyata. Foucault, dalam Nanang Martono (Martono, 2014, p. 110) menyebutkan bahwa kedisiplinan ini dilakukan untuk menyiapkan peserta didik menjadi tenaga kerja yang disiplin tinggi. Disiplin merupakan salah satu karakter penting yang harus dimiliki tenaga kerja agar mereka dapat sukses dalam pekerjaanya. Durkheim, dalam Nanang Martono (Martono, 2014, p. 111), menyatakan bahwa salah satu fungsi sekolah adalah menyiapkan individu memasuki lingkungan kerja, sehingga mereka harus dibekali dengan keterampilan-keterampilan khusus yang akan dibutuhkannya kelak. Tidak hanya itu, peserta didik juga harus mempelajari nilai-nilai serta karakteristik tenaga kerja, salah satunya adalah memiliki disiplin yang tinggi.

\section{Pola Asuh Orangtua}

\section{a. Pengertian Pola Asuh Orangtua}

Menurut Seto Mulyadi dkk, (Mulyadi, Basuki, \& Rahardjo, 2016, pp. 184-185) pola asuh dapat diartikan sebagai proses interaksi total antara orangtua dengan anak, yang mencakup proses pemeliharaan (pemberian makan, membersihkan dan melindungi) dan proses sosialisasi (mengajarkan perilaku yang umum dan sesuai dengan aturan daalam masyarakaat).

\section{b. Macam-macam Pola Asuh Orangtua}

Pola Asuh orangtua menurut Baumrind dalam (Silalahi, 2010, p. 198) adalah sebagai berikut:

1) Pola Asuh Autoritatif (Authoritative Parenting Style)

Pola pengasuhanseperti ini hangat, terlibat, menunjukkan dukungan dan rasa senang terhadap tingkah laku anak yang konstruktif, mempertimbangkan keinginan anak dan mendengarkan pendapat anak, memberikan berbagai alternatif pilihan, berkomunikasi dengan mereka secara jelas, menunjukkan rasa tidak senang terhadap tingkah laku yang buruk.

2) Pola Asuh Otoriter (Autoritarian parenting style) 
Pola pengaasuhan seperti ini memiliki kehangatan yang rendah serta keterlibatan secara positif yang rendah juga, tidak mempertimbangankan keinginan anak dan pendapat anak, memaksakan peraturan tanpa menjelaskan kepasa anak secara jelas, menunjukkan kemarahan dan perasaan tidak senang, berkonfrontasi dengan anak terhadap perilaku buruknya dan menggunakan hukuman.

3) Pola Asuh Permisif (Permissive parenting style)

Pola pengasuhan ini memiliki kehangatan yang cukup, mendukung pengekspresian secara bebas terhadap keinginan anak, tidak mengomunikasikan peraturan secara jelas dan tidak memaksa mereka untuk mematuhinya membiarkan ataupun menerima perilaku buruk anak, memiliki kedisiplinan yang tidak konsisten, tingkah laku yang mandiri, tidak menuntut ataupun mengendalikan.

4) Pola Asuh Tidak Terlibat (Uninvolved parenting style)

Pola pengasuhan seperti ini berkonsentrasi pada diri sendiri, secara umum tidak responsive, berusaha memuaskan diri sendiri dan tidak memedulikan kebutuhan anak, gagal untuk memonitor kegiatan anak, hubungan dengan anak cenderung depresif, penuh kecemasan, dan butuh akan kedekatan emosi akibat dari perceraian.

\section{c. Dampak Pola Asuh Orangtua}

1) Dampak Pola Pengasuhan Otoriter (Authoritarian ParentingStyle)

Anak dari pola pengasuhan seperti ini biasanya memiliki kecenderungan moody, murung, ketakutan, sedih, dan tidak spontan sebagaimana yang dikatakan oleh Martin \& Colbert, dalam Silalahi (Silalahi, 2010, p. 165).

2) Dampak Pola Pengasuhan Autoritatif (Authorritative Parenting Style)

Pola pengasuhan ini memberikan kesempatan kepada pada anak untuk berkembang ke arah positif. Alasan pertama, belajar untuk mengontol diri secara adil dan masuk akal sangat berguna bagi anak. Selain itu, orangtua yang penuh kasih sayang dan juga tegas membuat membuat anak menjadi lebih memerhatikan orang lain, percaya diri, dan asertif. Yang terakhir, Orangtua yang sensitif dan responsif terhadap kemampuan perkembangan anak dapat membuat anak belajar untuk mengambil tanggung jawab terhadap perilakunya sendiri. Pola pengasuhan autoritatif ditandai dengan tiga perilakupengasuhan yaitu: kehangatan (warmth), keseimbangan kekuasaan (balance of power), dan adanya tuntutan (demandingness)..

\section{d. Keterkaitan Antara Pola Asuh Orangtua Dengan Kedisiplinan Peserta Didik}

Dalam Moh Shochib (Shochib, 2014, p. 16) Keterkaitan pola asuh orangtua dengan kedisiplinan peserta didik dimaksudkan sebagai upaya orangtua dalam "meletakkan" dasar-dasar disiplin kepada peserta didik dan membantu mengembangkannya sehingga peserta didik memiliki kedisiplinan. Sebagaimana yang kita ketahui bahwa keluarga merupakan lembaga pertama bagi pendidikan anak. Di dalam keluargalah anak mulai mengenal aturan-aturan, norma, nilai yang mengatur hubungan atau interaksi antar anggota keluarga yang satu dengan yang lainnya. Dan di dalam keluarga anak menyatakan dirinya sebagai makhluk sosial. Pendidikan yang diterapkan di dalam keluarga sangat penting dalam membentuk kepribadian anak.Semua sikap yang dilakukan oleh anak sangat dipengaruhi oleh pendidikan keluarga terutama pendidikan yang diberikan dari orangtua. Orangtua merupakan pendidik pertama dan utama bagi anak-anak mereka karena dari merekalah anak-anak mendapatkan pendidikan. Dikatakan sebagai pendidik utama karena pendidikan dari orangtua menjadi dasar perkembangan dan kehidupan anak di kemudian hari. Pendidikan dalam keluarga merupakan usaha keluarga dalam mendewasakan anak melalui gaya kepemimpinan atau pola asuh yang di 
berikan untuk mendisiplinkan anak tergambar dari pemberian kasih sayang, ganjaran dan komunikasi.

\section{METHODS}

Dalam penelitian ini, objek penelitian adalah SMK Teknindo Jaya yang beralamat di Jl. Citayam Raya No.08 Des. Ratu Jaya Kec. Cipayung Kab. Depok, yang dilakukan sejak April 2019 sampai dengan Juli 2019. Jenis penelitian yang dilakukan adalah kuantitatif dengan metode survey. Populasi dari objek yang diteliti adalah keseluruhan siswa kelas X di SMKTeknindo Jaya yang berjumlah 125 peserta didik yang terdiri dari 3 kelas yaitu: XAP, XTKJ, dan XTKR, dengan sampel sebesar 95 yang menggunakan teknik simple random sampling. Sementara teknik pengumpulan data yang dilakukan adalah melalui wawancara dan studi literatur. Variabel independen yang diteliti adalah variabel X (Pola asuh orang tua) dan variabel dependen Y (Kedisiplinan). Teknik analisa data yang dilakukan adalah Uji Validitas dan Reliabilitas data dengan menggunakan rumus korelasi Pearson Product Moment dan Alpha Cronbach. Selain itu peneliti juga menggunakan rumus Regresi Linier sederhana, Koefisien Korelasi Product Moment, serta Koefisien Determinan.

Hipotesis dalam penelitian ini adalah diduga ada pengaruh yang positif antara pola asuh orangtua terhadap kedisiplinan peserta didik kelas X di SMK Teknindo Jaya. Untuk membuktikan hipotesis yang dilakukan dalam penelitian ini, peneliti menguji dengan menggunakan irumus t-Student.

\section{RESULTS \& DISCUSSION}

\section{Pengolahan Data Hasil Penelitian}

Data yang digunakan dalam penelitian ini diperoleh melalui instrumen kuesioner yang berisi 50 pertanyaan dengan menggunakan pilihan jawaban menggunakan skala likert yang diajukan kepada 95 responden.

\section{Karakteristik Responden}

Data-data yang diperlukan dalam penelitian ini diperoleh melalui instrumen kuesioner yang berisi 50 item pernyataan dengan pilihan jawaban menggunakan skala likert yaitu skalayang digunakan untuk mengukur sikap, pendapat dan persepsi seseorang atau sekelompok orang. Setelah dibagikan kepada 95 peserta didik SMK Teknindo Jaya maka didapat data responden. Data yang diperoleh dari penyebaran kuesioner ini merupakan data primer penelitian yang dilakukan.Pada bagian ini penelitian mendeskripsikan data hasil kuesioner sebanyak 95 peserta didik.Untuk memudahkan analisa data maka penelitian menyajikan dalam bentuk profil responden.

\section{a. Responden berdasarkan Jenis Kelamin}

Tabel 4.1

Profil Responden Berdasarkan Jenis Kelamin

\begin{tabular}{ccc}
\hline Jenis Kelamin & Frekuensi & Presentase Responden \\
\hline Pria & 53 & $56 \%$ \\
Wanita & 42 & $44 \%$ \\
TOTAL & $\mathbf{9 5}$ & $\mathbf{1 0 0 \%}$ \\
\hline
\end{tabular}

Sumber : Data diolah 
Berdasarkan tabel 4.1 dapat diketahui bahwa responden terbanyak ada pada jenis kelamin pria yaitu sebanyak 53 responden dengan persentase $56 \%$ dan sebanyak 42 dari jenis kelamin wanita dengan persentase $44 \%$.

\section{b. Profil Responden Berdasarkan Usia}

Tabel 4.2

Profil Responden Berdasarkan Usia

\begin{tabular}{ccc}
\hline Usia & Frekuensi & Presentase Reponden \\
\hline $14-15$ & 45 & $47 \%$ \\
$15-16$ & 50 & $53 \%$ \\
TOTAL & $\mathbf{9 5}$ & $\mathbf{1 0 0 \%}$ \\
\hline \multicolumn{2}{l}{ Sumber : Data diolah }
\end{tabular}

Berdasarkan tabel 4.2 dapat diketahui bahwa rentang usia responden yang terbanyak adapada usia 15-16 tahun sebanyak 50 responden dengan persentase $53 \%$, sedangkan rentang usia dengan responden paling sedikit adalah responden dengan usia 14-15 tahun sebanyak 45 responden dengan presentase $47 \%$.

\section{Analisis Data}

\section{Regresi Linier Sederhana}

Berdasarkan hasil penghitungan dengan menggunakan rumus statistik Regresi linier sederhana, maka diperoleh regresi sebesar $Y=12,4+1,14 X$

\section{Koefisien Korelasi}

Berdasarkan hasil penghitungan dengan menggunakan rumus statistik Korfisien Korelasi, maka diperoleh $\mathrm{r}=0,870$ atau $87 \%$. Berdasarkan rentang kategori koefisien korelasi, maka koefisien korelasi sebesar $87 \%$ digolongkan pada tingkat antara interval 0,80 - 1,000 yang artinya kontribusi pola asuh orangtua terhadap kedisiplinan peserta didik sangat kuat.

\section{Koefisien Determinasi}

Berdasarkan hashil penghitungan statistik dengan menggunakan rumus koefisien Determinasi, maka diperoleh $\mathrm{r}^{2}=75 \%$. Artinya, pengaruh pola asuh orangtua terhadap kedisplinan peserta didik sebesar $75 \%$ sisanya $25 \%$ dipengaruhi oleh faktor lain.

\section{Uji Hipotesis}

Pengujian ini dimaksudkan untuk mengetahui apakah variabel $X$ (pola asuh orangtua) dan variabel $\mathrm{Y}$ (kedisiplinan) berhubungan satu sama lain. Kemudian hasil dari $t_{\text {hitung }}$ dibandingkan dengan $t_{\text {tabel }}$ dengan hasilsebagai berikut:

$$
t=\frac{0,870 \sqrt{95-2}}{\sqrt{1-(0,870)^{2}}}=17,016
$$

Dari perhitungan diatas diperoleh nilai $t_{\text {hitung }}$ sebesar $=17,016$. Untuk menentukan $t_{\text {tabel }}$ maka $t_{\text {tabel }} \mathrm{a}=0,05$ dengan derajat kebebasan $(\mathrm{dk})=95-2=93$ adalah 1,986. Berdasarkan hasil perhitungan uji $\mathrm{t}_{\text {hitung }}$ dan besarnya $\mathrm{t}_{\text {tabel }}$ di atas, maka $\mathrm{t}_{\text {hitung }}>\mathrm{t}_{\text {table }}$ (17016 > 19858), sehingga $\mathrm{H}_{0}$ ditolak dan $\mathrm{H}_{\mathrm{a}}$ diterima artinya terdapat pengaruh yang signifikan antara pola asuh orangtua terhadap kedisiplinan peserta didik.

\section{Interprestasi Hasil Penelitian}

Dari hasil perhitungan koefisien korelasi di atas, maka dapat diketahui bahwa besarnya nilai koefisien korelasi antara pola asuh orangtua terhadap kedisiplinan peserta didik yaitu sebesar 0,870 sedangkan besarnya nilai koefisian determinasi yaitu sebesar $75 \%$, hal tersebut menunjukkan bahwa pola asuh orangtua (X) berpengaruh terhadap 
kedisiplinan peserta didik (Y), sedangkan sisanya sebesar 25\% diperoleh oleh faktor lainnya. Hasil uji regresi sederhana diperoleh nilai persamaan linearnya adalah $\mathrm{Y}=12,4$ $+1,14 \mathrm{X}$, artinya setiap kenaikan satu skor jawaban dari variabel pola asuh orangtua akan terjadi kenaikan 1,14. Sedangkan hasil dari uji hipotesa diperoleh nilai $t_{\text {hitung }}>t_{\text {tabel }}$ yaitu sebesar $17,016>1,9858$ sehingga $\mathrm{H}_{0}$ ditolak dan $\mathrm{H}_{\mathrm{a}}$ di terima. Sehingga terdapat pengaruh yang signifikan antara pola asuh orangtua terhadap kedisiplinan peserta didik.

\section{CONCLUSION}

Berdasarkan hasil penelitian yang dilakukan pada SMK Teknindo Jaya Depok mengenai "Pengaruh Pola Asuh Orangtua Terhadap Kedisiplinan Peserta Didik Pada SMK Teknindo Jaya Depok", maka peneliti penelitian ini dapat disimpulkan sebagai berikut:

1. Hasil penelitian diketahui bahwa pengaruh pola asuh orangtua memiliki kontribusi positif dan signifikan dalam meningkatkan kedisiplinan peserta didik, dapat dilihat dari hasil perhitungan $\mathrm{Y}=12,4+1,14 \mathrm{X}$. Artinya, terdapat pengaruh yang positif antara pola asuh orangtua terhadap kedisiplinan peserta didik SMK Teknindo Jaya Depok. Kesimpulannya adalah setiap peningkatan 1 kali variabel Y (kedisiplinan peserta didik) akan diikuti dengan kenaikan sebesar 1,14X dari variabel $\mathrm{X}$ (pola asuh orangtua).

2. Berdasarkan hasil uji korelasi secara keseluruhan didapat angka 0,870 atau $87 \%$, hal ini juga membuktikan bahwa kontribusi pola asuh orangtua terhadap kedisiplinan peserta didik sangat kuat. Dengan koefisien determinasi (KD) sebesar 75\%, hal tersebut menunjukkan bahwa pola asuh orangtua $(\mathrm{X})$ berpengaruh terhadap kedisiplinan peserta didik (Y), sedangkan sisanya sebesar 25\% diperoleh oleh faktor lainnya.

Dari hasil hipotesis uji $t_{\text {hitung }}>t_{\text {tabel }}$ yaitu sebesar $17,016>1,9858$ dengan demikian $\mathrm{H}_{0}$ ditolak dan $\mathrm{H}_{\mathrm{a}}$ diterima. Sehingga terdapat pengaruh yang signifikan antara pola asuh orangtua terhadap kedisiplinan peserta didik

\section{REFERENCES}

Arifin, A. A., \& Ummah, D. M. (2018). Pengaruh Pola Asuh Orang Tua Tunggal Dalam Keluarga Terhadap Kedisiplinan Belajar Siswa. JURKAM: Jurnal Konseling Andi Matappa, 2(1), 52. https://doi.org/10.31100/jurkam.v2i1.93

Danim, S. (2010). Perkembangan Peserta Didik. Bandung, Jawa Barat, Indonesia: Alfabeta.

Desmita. (2016). Psikologi Perkembangan Peserta Didik (6 ed., Vol. 1). Bandung, Jawa Barat, Indonesia: PT Remaja Rosdakarya.

Garmo, J. (2013). Pengembangan Karakter Untuk Anak: Panduan Pendidik. Jakarta Pusat, DKI Jakarta, Indonesia: Kesaint Blanc.

Lestari, S. (2012). Psikologi Keluarga: Penanaman Nilai dan Penanganan Konflik Dalam Keluarga (1 ed., Vol. 4). Jakarta, DKI Jakarta, Indonesia: Kencana.

Martono, N. (2014). Sosiologi Pendidikan Michel Foucault. Jakarta, DKI Jakarta, Indonesia: PT Raja Grafindo Persada.

Mulyadi, S., Basuki, A. M., \& Rahardjo, W. (2016). Psikologi Pendidikan: Dengan Pendekatan Teori-Teori Baru dalam Psikologi. Jakarta, DKI Jakarta, Indonesia: PT Raja Grafindo Persada. 
Shochib, M. (2014). Pola Asuh Orang Tua dalam Membantu Anak Mengembangkan Disiplin Diri (Revisi ed., Vol. 2). Bandung, Jawa Barat, Indonesia: Rineka Cipta. Silalahi, K. (2010). Psikologi Keluarga. Jakarta: PT Raja Grafindo Persada.

Sugiyono. (2016). Metode Penelitian Kuantitatif, Kualitatif, dan R\&D. Bandung, Jawa Barat, Indonesia: Alfabeta.

Tu'u, T. (2008). Peran Disiplin Pada Perilaku dan Prestasi Siswa. Jakarta, DKI Jakarta, Indonesia: Grasindo.

Werang, B. R. (2015). Manajemen Pendidikan di Sekolah. Yogyakarta: Media Akademi. 